\title{
ALIH KODE DAN CAMPUR KODE DALAM INTERAKSI PEMBELAJARAN BAHASA INDONESIA DI KELAS VIII F SMP NEGERI 2 BRANGSONG KABUPATEN KENDAL
}

\author{
Gina Dinnur Amalia, Herman J. Waluyo, Slamet Mulyono \\ Universitas Sebelas Maret \\ Surel: gina.dinewra@gmail.com
}

\begin{abstract}
Abstrak: Penelitian ini bertujuan untuk mendeskripsikan jenis alih kode dan campur kode, faktor penyebab alih kode dan campur kode, dan pola alih kode dan campur kode dalam pembelajaran bahasa Indonesia kelas VIII F SMP Negeri 2 Brangsong, kabupaten Kendal. Penelitian ini menggunakan metode deskripstik kualitatif dengan pendekatan studi kasus. Teknik yang digunakan adalah purposive sampling dan snow ball sampling serta teknik pengumpulan data melalui teknik rekam, teknik catat, dan wawancara. Teknik uji validitas data menggunakan triangulasi teori. Hasil penelitian ini adalah sebagai berikut: pertama, ditemukan 12 kali alih kode dalam bahasa Jawa sebanyak 4 kali dan 8 kali alih kode bahasa Arab; kedua, ditemukan campur kode sebanyak 44 kali yang terbagi menjadi bahasa Indonesia dialek Jakarta sebanyak 26 kali, bahasa Jawa sebanyak 12 kali, dan 6 kali dalam bahasa Inggris; ketiga, faktor penyebab alih kode dan campur kode dalam penelitian ini terbagi menjadi 5 faktor (a) pribadi dan pembicara, (b) mitra bicara, (c) tempat tinggal, (d) topik, serta (e) fungsi dan tujuan.
\end{abstract}

Kata kunci: alih kode, campur kode, faktor, pola

\section{CODE SWITCHING AND CODE MIXING IN INDONESIAN LANGUAGE LEARNING INTERACTIONS IN CLASS VIII F 2 JUNIOR HIGH SCHOOL 2 BRANGSONG, KENDAL REGENCY}

\begin{abstract}
The purpose of the research are kind of code-switching and code-mixing, the factor of the result from the code-switching and code-mixing; and the role of the code-switching and code-mixing in the Indonesian lerning of the seventh F class SMP N 2 Brangsong, Kendal regency. The research used descriptive qualitative method with case study approach.The research used purposive sampiling and snow ball sampling, then the technique of the collecting data by record, report, and interview. Validity test is triangulation theory. The result of the research are: the first, find out 12 code-switching in the javanese is four times and from Arab is 8 times; the second, find out the code-mixing consist of 44 times divided to be Indonesian dialeg from Jakarta is 12 times and english is 6 times; the third, factor of the result from the code-switching and code mixing from the research devided to be 5 factors (a) personal and speaker, (b) the partner of the speech, (c) the place, (d) topic, and (e) function and purpose.
\end{abstract}

Keyword: code-switching, code-mixing, factors

\section{PENDAHULUAN}

Manusia menggunakan bahasa sebagai alat untuk berkomunikasi dengan yang lain. Bahasa juga digunakan untuk memenuhi kebutuhan manusia yang merupakan makhluk sosial di dalam peristiwa sosialnya.
Dengan bahasa manusia dapat melakukan kerja sama, berinteraksi, dan juga untuk mengidentifikasikan diri sesuai dengan penguasaan bahasa mereka sendiri.

BASASTRA Jurnal Bahasa, Sastra, dan Pengajarannya 
Kemampuan berkomunikasi seseorang dipengaruhi oleh orang-orang yang berada di sekitarnya. Susmita (2015:1) mengatakan bahwa anak manusia mewarisi kesanggupan biologis untuk menguasai dan menggunakan bahasa, dan warisan ini bisa menjelaskan ciri-ciri universal yang terdapat dalam suatu bahasa-bahasa yang belum diketahui; tetapi tidak mewarisi sebuah bahasa tertentu. Anak-anak yang sejak kecil dikenalkan dengan bahasa ibu akan menggunakan bahasa ibunya untuk memenuhi kebutuhan seperti berkomunikasi dengan lingkungan sekitar.

Dalam berkomunikasi di mayarakat, penggunaan bahasa dipengaruhi oleh bahasa formal dan bahasa nonformal untuk membedakan usia, derajat, maupun situasi. Dalam ragam bahasa Indonesia, dikenal ragam baku dan ragam tak baku. Ragam tak baku digunakan ketika suasana tidak resmi, seperti percakapan pribadi bersama teman dekat dan juga dalam situasi santai. Untuk ragam baku ditandai kata yang tidak singkat atau lengkap dan biasanya digunakan di situasi yang resmi, misalnya pada pidato kenegaraan, rapat dinas, dan juga pada proses pembelajaran di sekolah.

Pendidikan nasional yang berlandaskan pada Undang-Undang Dasar Negara Republik Indonesia Tahun 1945 bertujuan untuk mengembangkan dan membentuk karakter bangsa dalam mencerdaskan kehidupan bangsa, dan mengembangkan potensi siswa untuk dipersiapkan menjadi manusia yang beriman dan bertakwa kepada Tuhan Yang Maha Esa, berakhlak mulia, sehat, berilmu, mandiri, dan bertanggung jawab. Bahasa Indonesia dalam hal ini memegang peranan yang penting, karena bahasa Indonesia digunakan sebagai bahasa pengantar dalam pembelajaran baik dari usia taman kanakkanak hingga perguruan tinggi.

Bahasa juga memegang peranan inti dalam pembelajaran, karena yang menyatukan antara guru dan siswa adalah bahasa. Dalam pembelajaran, siswa dituntut untuk aktif. Sekarang bukan hanya guru saja yang menyampaikan pembelajaran kemudian siswa mendengarkan, tetapi siswa harus dilibatkan dalam pembelaran. siswa juga dapat merespon pembelajaran. Pembelajaran bahasa Indonesia digunakan untuk meningkatkan kemampuan berbahasa Indonesia peserta agar baik dan benar, baik lisan mapun tulisan.

Kemampuan berbahasa Indonesia siswa yang tinggal di perkotaan berbeda dengan di pedesaan. siswa yang tinggal di perkotaan mayoritas sudah menguasai bahasa dengan baik karena terbiasa menggunakannya sebagai bahasa ibu, sedangkan penggunaan bahasa di pedesaan kurang karena dipengaruhi oleh bahasa daerah setempat yang digunakan dalam berkomunikasi. Di pedesaan percakapan dengan bahasa Indonesia akan didominasi bahasa daerah setempat, misalnya masuknya kode bahasa Jawa ke dalam bahasa Indonesia.

Kemampuan mengenal lebih dari satu bahasa (dwibahasa) dikenal sebagai dwibahasawan. Kedwibahasaan seseorang adalah kebiasaan seseorang dalam memakai dua bahasa dan menggunakan dua bahasa tersebut secara bergantian (Subyakto \& Nababan, 1992:103). Kedwibahasaan yang biasanya terjadi di Indonesia adalah peralihan bahasa daerah dan bahasa Indonesia serta bahasa Indonesia dan bahasa asing. Pengalihan kode tersebut dapat menyebabkan alih kode dan campur kode.

Menurut Achmad \& Abdullah (2013:159) alih kode adalah peralihan atau penggantian kode bahasa, baik antar ragam bahasa maupun dialek (ragam resmi atau formal ke ragam santai atau dari dialek ke dialek lainnya), juga peralihan bahasa (dari bahasa Indonesia ke bahasa daerah atau sebaliknya, juga ke dalam bahasa asing atau antar bahasa asing), dan dapat juga berupa

BASASTRA Jurnal Bahasa, Sastra, dan Pengajarannya

Volume 7 Nomor 1, April 2019, ISSN I2302-6405 
klausa atau kalimat lengkap yang mempunyai kaidah gramatika sendiri, yang dilakukan secara sadar karena alasan-alasan tertentu. sedangkan campur kode adalah peristiwa penggunaan dua buah kode bahasa atau lebih oleh penutur. Salah satu kode yang digunakan hanya berupa serpihan kata (partikel leksikal), kata frase, atau juga klausa suatu bahasa lain dalam suatu situasi (Achmad \& Abdullah, 2013:159).

Jenis alih kode dapat dibagi menjadi alih bahasa, alih ragam bahasa, dan alih tingkat tutur (Iqbal, dkk., 2011:16). Alih bahasa terjadi ketika penutur menggunakan bahasa Indonesia kemudian beralih ke dalam bahasa daerah atau bahasa asing. Alih ragam bahasa dapat berupa ragam sopan, ragam hormat, atau ragam santai. Alih tingkat tutur biasa terjadi dalam bahasa Jawa yang mengenal tingkat tutur rendah (ngoko), menengah (madya), dan tinggi (krama). Jenis campur kode dalam penelitian ini juga terbagi menjadi tiga: campur bahasa; campur ragam bahasa; dan campur tingkat tutur.

Iqbal, dkk. (2011:18) menyebutkan beberapa penyebab alih kode dan campur kode dipengaruhi oleh konteks dan situasi berbahasa yang terbagi menjadi: (1) pembicara dan pribadi, penutur mengubah pembicaraan dari situasi formal ke nonformal karena terbiasa menggunakan kosakata tersebut dalam berinteraksi; (2) mitra bicara, penutur awalnya menggunakan bahasa satu kemudian beralih kode menggunakan bahasa yang sama jika memiliki latar belakang bahasa yang sama; (3) tempat tinggal dan waktu pembicaraan berlangsung, alih kode dan campur banyak terjadi di tempat umum dalam suatu komunitas dengan banyak etnis; (4) modus pembicaraan, modus lisan lebih sering terjadi alih kode dan campur kode daripada menggunakan modus tulis; (5) topik, topik yang nonilmiah akan disampaikan dengan ragam nonformal (bebas dan santai). Interaksi yang nonformal ini akan menciptakan pembicaraan yang bebas dan santai, sehingga terjadi penyisipan unsur bahasa lain atau campur kode; (6) fungsi dan tujuan, ungsi pembicaraan akan disesuaikan dengan tujuan berkomunikasi, misalnya ungkapan dengan tujuan tertentu seperti perintah, menawarkan, mengumumkan, memarahi, dan sebagainya. Penutur menggunakan bahasa yang menurut fungsi yang dikehendaki sesuai dengan situasi atau konteks; serta (7) ragam dan tingkat tutur bahasa, alih kode dan campur kode lebih sering timbul pada penggunaan ragam nonformal dan tutur bahasa rendah dibandingkan dengan penggunaan ragam bahasa karena penutur akan mempertimbangkan topik atau situasi tertentu yang disesuaikan dengan mitra tutur.

Fenomena alih kode dan campur kode ini juga terjadi di SMP Negeri 2 Brangsong. Bahasa pengantar yang digunakan dalam pembelajaran seharusnya adalah bahasa Indonesia karena pembelajaran termasuk dalam situasi formal, namun guru menggunakan unsur bahasa daerah dan bahasa asing dalam interaksinya dengan siswa. Hal ini termasuk dalam penyimpangan fungsi bahasa Indonesia sebagai bahasa pengantar di dalam pembelajaran.

Oleh karena itu, peneliti tertarik menganalisis penggunaan alih kode dan campur kode dalam pembelajaran bahasa Indonesia di sekolat tersebut. Dalam penelitian ini peneliti mengambil judul "Alih Kode dan Campur Kode Guru dan Siswa Pada Pembelajaran Bahasa Indonesia SMP Negeri 2 Brangsong Kendal".

\section{METODE PENELITIAN}

Penelitian ini berlangsung selama dua minggu pada bulan Mei 2018. Objek penelitian ini adalah penggunaan bahasa dalam interaksi pembelajaran bahasa Indonesia di kelas VIII F SMP Negeri 2 Brangsong, kabupaten Kendal. Penelitian ini 
berupa deskriptif kualitatif dengan pendekatan studi kasus. Data dan sumber data didapatkan dari transkrip interaksi pembelajaran bahasa Indonesia. Teknik yang digunakan adalah purposive sampiling dan snow ball sampling. Teknik pengumpulan data penelitian ini adalah wawanacara, catat, dan rekam. Penelitian ini diuji menggunakan teknik Uji Validitas trianggulasi teori dan trianggulasi metode. Setelah data divalidasi, data dianalisis menggunakan metode padan yang terdiri dari tiga teknik: (1) teknik hubung banding menyamakan; (2) teknik hubung banding membedakan; dan (3) teknik hubung banding menyamakan hal pokok.

\section{HASIL DAN PEMBAHASAN}

\section{Jenis Alih Kode}

Alih kode yang ditemukan dalam penelitian ini adalah peralihan dari bahasa Indonesia ke dalam bahasa Jawa dan bahasa Arab. Bahasa Jawa digunakan oleh penutur karena siswa SMP Negeri Brangsong mayoritas berbahasa ibu bahasa Jawa sedangkan bahasa Arab digunakan karena mayoritas agama siswa adalah Islam sehingga mengetahui makna bahasa tersebut. Berikut adalah beberapa penggunaan bahasa Jawa dan bahasa Arab dalam penelitian ini.

\section{Alih Kode dalam Bahasa Jawa}

$\begin{aligned} \text { (103) Guru } \quad \text { : } & \text { "Apakah di puisi ada } \\ & \text { sudut pandang?" } \\ \text { (104) Siswa : } & \text { "Tidak." } \\ \text { (105) Guru }: & \text { "Apakah di puisi ada } \\ & \text { pilihan kata? Hayo } \\ & \frac{\text { ke! (Ayo kamu!) }}{\text { Apakah di puisi ada }} \\ & \text { pilihan kata? Apakah } \\ & \text { di puisi ada pilihan } \\ & \text { kata?" }\end{aligned}$

Penggunaan bahasa tersebut di atas terjadi ketika guru bertanya "apakah di puisi ada pilihan kata?" kepada siswa tetapi tidak mendapatkan tanggapan. Pada saat pembelajaran tersebut siswa terlihat tegang karena tidak dapat menjawab pertanyaan guru. Guru kemudian membuat suasana santai dengan berkata "hayo ke!". Hal ini menyebabkan guru menggunakan bahasa nonformal dalam pembelajaran karena ingin menciptakan suasana santai untuk mengurangi ketegangan.

Kalimat "hayo ke!" berasal dari dua kata bahasa Jawa. Kata hayo atau "ayo" dan kowe atau "kamu". Kata ayo dalam bahasa Jawa termasuk dalam ragam ngoko (Piyono, 2004:38). Tim Dunia Pelajar (2009:32) juga memasukkan kosakata ayo dalam bahasa Jawa ngoko. Hal ini menunjukkan bahwa kata ayo merupakan tingkat tutur ngoko atau rendah karena ngoko termasuk dalam bentuk dasar dari semua leksikon di dalam bahasa Jawa (Rahardi, 2016:64). Berikut tingkat tutur kata ayo dalam bahasa Jawa.

\section{Tabel 1: Tingkat Tutur Kata Ayo dalam}

\section{bahasa Jawa}

\begin{tabular}{|c|c|c|}
\hline Ngoko & Krama & $\begin{array}{c}\text { Krama } \\
\text { Inggil }\end{array}$ \\
\hline $\begin{array}{l}\text { ayo, } \\
\text { enya }\end{array}$ & manga & sumangga \\
\hline
\end{tabular}

kowe berubah menjadi ke karena terjadi pelesapan kata. Pelesapan kata adalah penghilangan suatu unsur tertentu dari satu kalimat atau sebuah teks (Alwi, 2003:415). Hal ini menyebabkan terjadinya penghilangan unsur dari kata kowe menjadi ke. Kata "kowe" dalam bahasa Jawa merupakan kata ganti orang kedua yang bermakna kamu. Kata tersebut termasuk dalam tingkat tutur ngoko atau rendah (Piyono, 2004:41). Raharjo (2012:34) menyatakan bahwa kata kowe termasuk dalam bahasa Jawa ngoko. 
Tabel 4.2: Tingkat Tutur Kata Kowe dalam Bahasa Jawa

\begin{tabular}{ccc}
\hline Ngoko & Krama & $\begin{array}{c}\text { Krama } \\
\text { Inggil }\end{array}$ \\
\hline kowe & sampeyan & Panjenengan \\
\hline
\end{tabular}

\section{Alih Kode dalam Bahasa Arab}

Alih kode bahasa Arab pada penelitian ini adalah salam yang digunakan oleh umat Islam ketika bertemu atau berpisah.

$\begin{aligned} \text { Guru : } & \text { "Assalamu 'alaikum } \\ & \text { warohmatullahi } \\ & \text { wabarokatuh. (Semoga } \\ & \text { keselamatan, keberkahan, } \\ & \text { dan kasih sayang dari } \\ & \text { Allah } \\ & \text { Anda/Kalian)" menyertai }\end{aligned}$

Penyebab alih kode di atas adalah mayoritas agama siswa kelas VIII F dan guru adalah Islam sehingga guru mengucapkan salam pembuka pembelajaran dengan Assalamu 'alaikum warohmatullahi wabarokatuh. Alih kode di atas termasuk ke dalam alih kode ekstern karena adanya peralihan bahasa dari bahasa Indonesia ke dalam bahasa Arab (Iqbal, dkk., 2010:16).

\section{Campur Kode}

Campur kode pada penelitian ini ditemukan dalam bahasa Indonesia dialek Jakarta, bahasa Jawa, dan bahasa Inggris. Berikut adalah penjelasan mengenai penggunaan bahasa tersebut.

\section{Campur Kode dalam Bahasa Indonesia Dialek Jakarta}

(721)

(722)

$\begin{array}{lllr}\text { Siswa 25 } & : & \text { "Tidak." } & \\ \text { Guru } & : & \text { "Nggak, } & \text { ya? } \\ & & \text { Nggak? } & \text { Tidak. } \\ & \text { Ayo } & \text { kelompok } \\ & \text { lain, } & \text { ada } \\ & \text { tanggapan } & \text { apa } \\ & \text { ndak?" }\end{array}$

Penggunaan bahasa di atas (722) terjadi karena siswa 25 mengatakan kata nggak ketika diberi pertanyaan oleh guru. Guru bertanya kembali dengan mengatakan, "ha?" dan kemudian siswa 25 mengoreksi dengan berkata, "tidak". Kata nggak masuk dalam daftar kata dialek Jakarta (Muhajir, 1984:169). Percampuran kata nggak dalam bahasa Indonesia menyebabkan terjadinya campur kode intern adalah percampuran antara ragam bahasa Indonesia dengan ragam bahasa Jawa.

Penggunaan bahasa (722) terjadi ketika guru mengingatkan siswa 25 untuk tidak menggunakan bahasa nonformal (nggak) dalam pembelajaran, sehingga guru mengoreksi dengan berkata, "Nggak, ya? Nggak? Tidak ...". Guru mengatakan jika penggunaan bahasa dialek Jakarta tersebut karena faktor ketidaksengajaan.

\section{Campur Kode dalam Bahasa Jawa}

(181) Guru : "Apa yang kamu baca fabelnya? Fabel itu apa to?"

(182) Siswa : "Cerita binatang."

Kalimat tanya di atas (181) menunjukkan bahwa guru ingin mengetahui tingkat pemahaman siswa terhadap materi yang diajarkan. Kalimat tanya tersebut jika diubah dalam bahasa Indonesia maka akan menjadi, "Apa yang kamu baca fabelnya? Fabel itu apa ya?".

Kata "to" tersebut merupakan bahasa Jawa dialek Yogyakarta dan Surakarta. Rahardi (2011:89) mengatakan bahwa 
wilayah Yogyakarta dan Surakarta adalah tempat tumbuh dan berkembangnya bahasa Jawa dialek standar, seperti kata-kata kok, lho, lho nggih, mbok yo, to, to yo, dan beberapa kata yang bercirikan bahasa Jawa dialek standar. Standar di sini dapat diartikan sebagai tingkat tutur madya atau menengah karena tingkatan yang digunakan tidak terlalu tinggi dan tidak terlalu rendah atau dapat dikatakan kadarnya sedang-sedang saja (Rahardi, 2011:63).

\section{Campur Kode dalam Bahasa Inggris}

Kata ending bermakna akhiran atau pengakhiran (Johrls \& Hasly, 2006:213). Kata tersebut sering digunakan pada materi alur dalam unsur intrinsik untuk menggantikan kata penyelesaian cerita.

Guru : "Sekarang apa itu buku fiksi? Buku fiksi adalah buku rekaan atau ciptaan itu biasanya diambil dari kehidupan sehari?"

(71) Siswa : "Hari."

(72) Guru : "Diambil dari kehidupan sehari-hari. Tetapi ending ceritanya itu menurut pe?"

(73) Siswa : "Ngarang."

Konteks interaksi di atas terjadi ketika guru menjelaskan mengenai buku fiksi yang merupakan buku rekaan atau ciptaan yang diambil dari kehidupan sehari-hari dan penyelesaian cerita diciptakan sendiri oleh pengarang. Guru mengatakan hal tersebut karena pembiasaan guru yang menggunakan kata ending untuk menggantikan kata penyelesaian.

\section{Penyebab Alih Kode dan Campur Kode}

Penyebab alih kode dan campur kode yang ditemukan dalam penelitian ini adalah: (1) pembicara dan pribadi, penutur kurang mengetahui mengenai kata baku dalam bahasa Indonesia dan terbiasa menggunakan bahasa tersebut dalam berkomunikasi; (2) mitra bicara, penutur menyesuaikan penggunaan bahasa sesuai dengan mitra tutur. Siswa dengan siswa akan bekomunikasi menggunakan bahasa Jawa untuk menciptakan suasana santai; (3) tempat tinggal, penggunaan bahasa penutur dipengaruhi oleh asal tempat tinggal maupun teman yang berasal dari daerah lain; (4) topik, penutur menyesuaikan bahasa yang dipilih sesuai dengan topik yang hendak disampaikan kepada mitra tutur; serta (5) fungsi dan tujuan, beberapa fungsi alih kode dan campur yang ditemukan dalam penelitian ini adalah mencairkan suasana, mengklarifikasi maksud tertentu, kemudahan dalam mengekspresikan pesan, serta pengecekan pemahaman.

\section{SIMPULAN}

Simpulan penelitian ini adalah sebagai berikut. Pertama, alih kode yang terjadi dalam penelitian adalah penggunaan bahasa Jawa dan bahasa Arab. Bahasa Arab sering digunakan dalam penelitian ini karena mayoritas siswa SMP Negeri 2 Brangsong beragama Islam dan kalimat tersebut sering digunakan untuk salam pembuka dan penutup pembelajaran. Kedua, campur kode dalam penelitian ini menggunakan bahasa Indonesia dialek Jakarta, bahasa Jawa, dan bahasa Inggris. Campur kode yang sering digunakan dalam penelitian adalah bahasa Indonesia dialek Jakarta karena penutur ingin menciptakan suasana santai ketika pembelajaran. Ketiga, alih kode dan campur kode dalam penelitian disebabkan karena faktor pembicara dan pribadi, mitra bicara, tempat tinggal, topik, serta fungsi dan tujuan, beberapa fungsi alih kode dan campur yang ditemukan dalam penelitian ini adalah mencairkan suasana, mengklarifikasi maksud tertentu, kemudahan dalam 
mengekspresikan pesan, serta pengecekan pemahaman.

Penelitian ini menggunakan interaksi pembelajaran bahasa Indonesia di kelas VIII F SMP Negeri 2 Brangsong, kabupaten Kendal untuk mendapatkan data alih kode dan campur kode. Peneliti lain harus meningkatkan penelitian supaya ilmu mengenai alih kode dan campur kode semakin berkembang. Guru juga harus mengenalkan kata ganti bahasa daerah dan bahasa asing ke dalam bahasa Indonesia sehingga alih kode dan campur kode dalam pembelajaran akan berkurang. Lembaga pendidikan juga harus meningkatkan model pembelajaran yang menggunakan bahasa Indonesia sebagai bahasa pengantar supaya kemampuan penggunaan berbahasa Indonesia siswa semakin meningkat.

\section{REFERENSI}

Achmad \& Abdullah, A. (2012). Linguistik Umum. Jakarta: PT Gelora Aksara Pratama.

Alwi, H., Dardjowidjodjo, S., \& Moeliono, A.M. (2003). Tata Bahasa Indonesia Edisi Ketiga. Jakarta: Balai Bahasa.

Iqbal, dkk. (2011). Sosiolinguistik: Teori dan Praktik. Surabaya: Lima-lima Jaya.

Johrls \& Hasly. (2006). An English -Indo Dictionary. Jakarta: Gramedia Utama.

Muhajir. (1984). Morfologi Dialek Jakarta: Afiksasi dan Reduplikasi. Jakarta: Djambatan.

Piyono, Joko. (2004). Kawruh Pepak Basa Jawa Anyar. Surakarta: Pustaka Mandiri Surakarta.
Rahardi, K. (2015). Kajian Sosiolinguistik: Ihwal Kode \& Alih Kode. Bogor: Ghalia Indonesia.

Subyakto, S.U. \& Nababan. (1992). Psikolinguistik: Suatu Pengantar. Jakarta: Gramedia Pustaka Utama.

Susmita, N. (2015). Alih Kode dan Campur Kode dalam Pembelajaran Bahasa Indonesia di SMP Negeri 12 Kerinci. Jurnal Penelitian Universitas Jambi Seri Humaniora, 17(2), hal. 87-98. Diperoleh pada 4 Januari 2018, dari https://online-journal.unja.ac.id. 